\title{
Strategic Planning Framework for Land Consolidation in China: A Top-level Design Based on SWOT Analysis
}

\author{
Jinming Yan ${ }^{\mathrm{a}}$, Fangzhou Xia ${ }^{\text {ab }}$, Helen X. H. Bao ${ }^{\mathrm{b}^{*}}$ \\ ${ }^{a}$ Department of Land Management, Renmin University of China, Beijing, China \\ ${ }^{b}$ Department of Land Economy, University of Cambridge, Cambridge, UK
}

\begin{abstract}
:
China is in the midst of an unprecedented and critical period of strategic opportunities for land consolidation. In this process, the country has been confronted with new situations, opportunities, and serious challenges, all of which urgently require top-level design of strategic planning framework for land consolidation. Based on a SWOT analysis, we propose a strategic planning framework for land consolidation at the national level, with a focus on clarification of internal Strength-Weakness strategies and external Opportunity-Threat strategies involved in the land consolidation process. Whereas it can be concluded that land consolidation in China has not yet entered the stage of landscape-ecological pattern, it is on the brink of that stage. Thus, the proposed strategic plan should provide strong protection for continuous promotion of land consolidation through the application of a top-down and comprehensive design considering agriculture production, livelihood and ecology as comprehensive targets. Meanwhile, it should also unswervingly adhere to the "red line," optimize the layout of urban and rural land use and propel a new landscape-ecological pattern of land consolidation. In this way, strategy-oriented support can be provided to improve land consolidation implementation and ensure that it is stable, coordinated and effective.
\end{abstract}

Keywords: Land consolidation, strategic planning framework, landscape-ecological pattern, balanced development, top-level design

\footnotetext{
* Corresponding author. Tel.: (44) 01223337 116; fax: (44) 01223337130.

E-mail addresses: yanjinming@ mparuc.edu.cn (Jinming Yan), ark_xiafangzhou@ @otmail.com (Fangzhou Xia), hxb20@cam.ac.uk (Helen X. H. Bao)
} 


\section{Strategic Planning Framework for Land Consolidation in China: A Top-level Design Based on SWOT Analysis}

\section{Introduction}

The balance between urban and rural area development has a great impact on the social and economic lives of residents. Studies in this field are of both theoretical and practical importance for public policy makers, practitioners, and academics. In China, urbanization takes on particular significance because it is an integral part of policies to manage economic transition. Consequently rural development had, for many decades, received less attention than urban development (Wang et al, 2014). In recent years the significance of rural factors in supporting urbanization, such as food security, labor mobility, and ecological conservation, has eventually drawn increasing attention from Chinese policymakers. Unfortunately the long-time neglect of rural development has already caused some serious problems. In particular, despite the fact that China's rapid urbanisation has contributed greatly to economic growth, it has also led to huge losses of farmland (Zhao, 2011). From 2002 to 2010, a total of 3.49 million hectares of new construction land were added to the existing stock, which means about 200,000 hectares of cultivated land were lost annually during this period (Yan, 2010). Meanwhile, even though the Household Responsibility System (HRS) ${ }^{1}$ has greatly improved agricultural productivity in the early years, it also gave raise to land fragmentation due to the limited availability of arable land. This resulted in low efficiency, high travel costs and difficulties in agricultural management (Nguyen et al., 1996). In addition, some social problems have also been overlooked in the rural areas, such as scattered rural settlements (Xia et al, 2014) and hollowed villages (Li et al, 2014). Left without being addressed, these issues led to further problems such as low efficiency of rural residential land use, lateral expansion of rural dwellings at the expense of farmland loss, and deterioration of rural residential environment (Liu and Liu, 2010 and Wang et al., 2010). To resolve these issues while sustaining satisfactory economic growth, the Chinese government has been exploring strategies to maintain a balance between rural and urban development. An important strategy is the "New Rural Construction" scheme (NRC) ${ }^{2}$ put forward in 2005 by the central government with a clear focus on improving rural living conditions during the rural residential land consolidation process. Land consolidation is a crucial step to realize this plan.

In this paper, land consolidation is defined as a process by which segmented land parcels are integrated to form centralized and continuous lands in areas where the lands are not efficiently used, misused, unused or damaged by production, manufacture or natural disasters (Yan et al, 2012). Land consolidation aims to protect farmland, improve the "New Rural Construction" and urban-rural integration development. Land consolidation enlists the idea of the trinity of quantity control, quality management as well as ecological management and protection to improve land utilization efficiency. To meet the demands of the Chinese land reform as a whole and as an important aspect of the new urbanization strategy, it should be noted that China is in the midst of an

\footnotetext{
${ }^{1}$ The Household Responsibility System was introduced in 1981. Under this system the production of agricultural goods and the management of farmland are entrusted to individual farming households through long-term contracts (Tan et al., 2006).

${ }^{2} \mathrm{NRC}$ is designed to promote comprehensive and coordinated sustainable development of the economy and society. This strategy focuses on addressing issues that lead to low income growth for farmers, poor agricultural production conditions, among other ways in which rural development does not meet the needs of farmers. The operative principles involve improvement of agriculture productivity, lifestyle, rural civilization, village improvement and democratic management. The strategy ultimately aims to achieve economic prosperity throughout a civilized and harmonious Chinese countryside, including establishing good facilities and maintaining a beautiful environment.
} 
important period of strategic opportunities for land consolidation as an integrated element of its economic and social development. At present, the twelfth five-year (2011-2015) economy and social development period has almost come to an end and the thirteenth five-year (2016-2020) period needs a definite strategic planning framework for land consolidation (SPFLC) particularly at both the "top-down" and "bottom-up" views.

Thus this paper aims to address issues including the absence of current SPFLC studies, as well as the blurred background analysis, unclear strategic planning framework, confusion of objectives and tasks, ambiguous regional division and inadequate guarantee measures associated with land consolidation. For the first time, we designed SPFLC in China at the national level to guarantee China's food security, as well as to strike a balance between the maintenance of ecological systems and promotion of urban-rural integration. In this paper, we firstly discuss the features and approaches of land consolidation and the urgency of SPFLC design in China. Applying SWOT analysis to the design of strategic planning framework for land consolidation, we provide an account of the historical and current practice of land consolidation practices in China to analyze its strengths, weaknesses, opportunities and threats. We then proposed a SPFLC that aims to ensure that land consolidation is scientifically based, resolves the resource bottleneck and ensures that land consolidation is pertinent and stable. The rest of the paper is organized as follows. A SWOT analysis of land consolidation in China is given in Section 2, followed by a strategic planning framework for land consolidation presented in Section 3. Section 4 provides conclusions and discussions on policy implications.

\section{An SWOT analysis}

\subsection{The practice of land consolidation in China}

Being considered as an alternative to mainstream balance development, land consolidation, which has proven effective particularly in creating better livelihood in rural and urban areas and improving the sustainable use of resources and public facilities, has been taken as a particular kind of rural development instrument (Miranda et al., 2006; Li et al., 2014). In addition, land consolidation has been widely regarded as a tool for improving the effectiveness of land cultivation and for supporting rural production (Sklenicka, 2006; Van Dijk, 2007). It is also a useful tool for facilitating environmental management (Van Lier, 2000; Crecente et al., 2002; Gonzalez et al., 2004) and other social and economic issues related to managing the development of rural areas (Wittlingerova and Kriz, 1998).

Due to the large population and limited land resources, the loss of good quality agricultural land to urban and rural settlement expansion is one of the most discussed resource issues in China,(Li and Wang, 2003, Lin and Ho, 2003, Ding, 2003 and Lin, 2010). The loss of agricultural land threatens the grain security of the whole country, while excessive control of urban expansion can also have adverse effects on the development of industrialization and urbanization (Li et al., 2014). These two challenges are difficult to reconcile, but one important solution which is widely accepted by the society is improving the efficiency of land use in both urban and rural areas. Thus land consolidation could be an important approach for sustainable development and spatial restructuring for the city and countryside unification (Long, 2014, Long et al., 2012 and Huang et al., 2011).

Land consolidation has been implemented in China since the mid-1990s and normally is carried 
out by executing the land consolidation projects (LCPs). From 2006 to 2010, 124,085 LCPs funded by the national and provincial government were approved and the total areas of these projects were $110,600 \mathrm{~km}^{2}$ (Zhang et al., 2014). Meanwhile, more than 115,127 LCPs were competed, with great changes occurring to LCPs' scope, objectives, content and pattern. Originally, the scope of consolidation extended only to the development and consolidation of scattered lands, but it has evolved into a process that involves integrations of fields, water, roads, forests and villages. The consolidation objective started as the simple goal of supplementing cultivated land but has evolved into the protection of farmland and participation as a coordinated element of China's NRC and the overall process of development of urban and rural areas. Previously, consolidation focused on enlarging the area of cultivated land, but this focus transformed into comprehensive management, comprising "quantity control, quality management and ecological management"(Xia et al., 2014).

Previously, China had launched the "National Land Consolidation Plan (2011-2015)" on 27 March 2012 with the aim of constructing 26.67 million ha high-quality farmland to ensure national grain security and consolidate 300 thousand ha rural residential land to rationalizing rural settlement (Li et al.,2014). However, the "National Land Consolidation Plan (2011-2015)" has almost come to an end and land consolidation in China need a new strategic planning framework for a new period (2016-2020) since the social and economical situation has undergone tremendous changes in a large-scale urbanization process (Wang et al, 2014). Further, China plans that another more than 26.667 million $\mathrm{hm}^{2}$ of high-quality, stable-yield farmland will be added during the $13^{\text {th }}$ Five-Year Plan (2016-2020). The total area will reach 53.334 million $\mathrm{hm}^{2}$ by 2020, accounting for more than $50 \%$ of the national basic farmland. Therefore, 2.64 million $\mathrm{hm}^{2}$ of cultivated land will be supplemented by consolidation, including 1.19 million $\mathrm{hm}^{2}$ from agricultural land, 0.4 million $\mathrm{hm}^{2}$ by reclamation of damaged land and 1.05 million $\mathrm{hm}^{2}$ from unused land suitable for cultivation. Moreover, a total of 0.3 million $\mathrm{hm}^{2}$ of rural settlement will be consolidated during the $12^{\text {th }}$ Five-Year Plan, with an additional 0.45 million $\mathrm{hm}^{2}$ to be consolidated during the $13^{\text {th }}$ Five-Year Plan, toward a total of 0.75 million $\mathrm{hm}^{2}$ of rural settlement consolidated by 2020 (Yan, et al. 2012). As such, there is still a long way ahead for LAND CONSOLIDATION to facilitate the agricultural and rural development which imminently calls for the guidance of a scientific and practical SPFLC, analyzing internal and external environments, stakeholder participation, and implementation (Halla, 2007; Ogu, 2000; Wong et al., 2006).

\section{$\underline{2.2 S \backslash W O \backslash T \text { Identification }}$}

As observed in literature, SWOT analysis surrounding the procedural or master-planning approach has been widely analyzed in existing literature (Choguill,1999; Halla and Majani, 1999; Healey, 1994; Graaf and Dewulf, 2007), and the proposed SWOT analysis can be applied to strategic planning framework design, as well as to site monitoring in order to better inform its management (Davidson, 1996; Halla, 2007; Rocco et al., 2014). Firstly we should identify strengths, weaknesses, opportunities and threats of land consolidation in China to ensure a successful implementation (Davidson, 1996; Halla, 2002; Steinberg, 2005; Wong, et al., 2006).

\section{Strengths $(S)$}

S1: To date, a certain amount of experience has been accumulated in land consolidation. The related policy system and technique standards were initially shaped when the "National Land Consolidation Program (2001-2010)" began to be implemented. From 1999 to 2008, land consolidation work was highly effective, and the fund for land consolidation across the country 
totaled approximately 100 billion CNY each year. Specifically, during the period of the 11th Five-Year Plan (2006-2010), China invested approximately 30 billion CNY in land consolidation, designating more basic farmland of high quality, improving the comprehensive capacity of food production and promoting intensive and effective use of land resources. During the period of the 12th Five-Year Plan, China will invest more than 60 billion CNY to strengthen land consolidation as part of the new rural development processes. This new round of land consolidation will add 2.7754 million $\mathrm{hm}^{2}$ of new cultivated land has played an extremely important role in protecting the 120 million $\mathrm{hm}^{2}$ of existing cultivated land.

S2: Land consolidation has an extensive base of support. With the development of LC practices, people all over the country have a more in-depth understanding of land consolidation. Farmers have strongly indicated their desire to further improve their production conditions (and thereby develop the rural economy) by advancing land consolidation.

S3: Land consolidation has huge potential and bright prospects (Liu, 2011). Currently, China's rural land use follows an extensive pattern, with the rural residential land per capita of $218.69 \mathrm{~m}^{2}$, which is $78.69 \mathrm{~m}^{2}$ higher than the national standard of $140 \mathrm{~m}^{2}$ per capita ${ }^{3}$. As a result, there are vast opportunities for improved utilization and intensification of land as a major contribution to the national economy. The "three old reform" policy ${ }^{4}$ for renewal and renovation of urban China also offers a huge potential for LC.

\section{Weaknesses $(W)$}

W1: Lack of coordination and objectives remain singular. At present, the primary goal of China's land consolidation is still limited to increasing the total area of arable land. There is a lack of unification between achievement of this goal, planning related to farmers' production and livelihoods and environmental improvement. There is also a lack of overall design in the designation of areas as field, water, road, forest and village land and a lack of coordination between and within counties. In addition, the supporting facilities used for economic development are insufficient. As a result, it is difficult for land consolidation to fulfill its function in practice.

W2: Efforts and attention related to the protection of rights in rural and urban land are insufficient. Serious conflicts have arisen regarding the rights of persons with some direct relation to the land, including various types of inequalities in the distribution of increases in land value. In particular, the farmers themselves have taken insufficient measures to protect their own interests. These factors have led to significant losses in farmers' interest in using the lands that are most directly of concern in land consolidation.

W3: There has been a notable lack of support in the forms of sufficient theoretical preparation, rational paradigm and strategic thinking (Wu et al, 2011). Due to the limited amount of basic academic research on land consolidation in China, there is still no high-impact hypothesis underlying China's land consolidation, and as a result, the country is still lacking in land consolidation planning, design and technological support systems, including related techniques and staff. In addition, there are major gaps in the legal construction of land consolidation in China, which currently has no laws or regulations that specifically address land consolidation. These issues constitute great obstacles to the smooth implementation of land consolidation.

\section{Opportunities $(\mathrm{O})$}

\footnotetext{
${ }^{3}$ This national standard is according to the "Standard for planning of town (GB 50188 - 2007)."

4 "Three old reform" policy refers to the "old town, old factories, old villages" reform, which means to re-layout the old town, remold the old factory and re-build the old village.
} 
O1: The works undertaken as New Rural Construction and the coordinated development of urban and rural areas are intensifying during the implementation of China's 12th Five-Year Plan (2011-2015). This represents an important period of strategic opportunity for the country's economic and social development and clarifies the tasks that are expected of land consolidation in the near future. The implementation of major land consolidation projects is specifically included in the government's list of the 12 engineering projects of New Rural Construction for this period. The National Land Consolidation Program (2011-2015) is already being implemented. Land consolidation will be further developed and will find significant new opportunities through the planned increases of 26.667 million $\mathrm{hm}^{2}$ in the total area of China's high-standard farmland, new rural construction work and coordinated development of China's urban and rural areas.

O2: As land becomes the scarcest resource in China, market demand, especially the need of construction land, is growing increasingly stronger. Given the enormous potential of land consolidation and the high levels of demand on industrial and urban land development, the value of farmland and ecological land is actually gaining a further boost from rapid industrialization and urbanization. This in turn creates a strong social demand for further land consolidation.

O3: China's national government has paid significant attention to land consolidation, and its local governments have responded positively. In particular, land consolidation was mentioned in Central File No. 1 and the Report on the Work of the Government, which means land consolidation is a priority for central and local governments. The implementation of land consolidation is specifically included among the major national scientific projects identified in the document entitled "Agriculture and Food Science and Technology Development Plan 2009-2020," proposed by 14 ministries (including the Ministry of Science and Technology). The State has issued successive documents that explicitly support many aspects of land consolidation, including funding and policy support. The enthusiasm of local governments is unprecedentedly high. Therefore, as an important tool and platform of urban and rural work, land consolidation is faced with great opportunities.

\section{Threats (T)}

T1: The situation concerning the protection of agricultural land, especially cultivated land, is severe. By 2020, China's population will reach 1.45 billion. To ensure food security in China, the Outline of National Overall Planning on Land Use (2006-2020) defines the goal of developing 120.33 million $\mathrm{hm}^{2}$ of quality arable land. However, China's rapid urbanization inevitably encroaches upon farmland. Combined with the lack of reserve cultivated land resources in China, the situation concerning the protection of agricultural land (especially cultivated land) remains very serious and poses a significant threat to LC in China. The application of LC on a massive scale is a new and complicated systemic project. As such, it is very challenging and requires the development of reasonable yet innovative design at all levels.

T2: Conflicts between the supply and demand of land have become evident as China has reached an advanced stage of accelerated urbanization, with the area of cultivated land annually converted to construction currently at 200-330 thousand $\mathrm{hm}^{2}$. Land is necessary to promote the development of social economy and it also seems clear that the demand for land will remain at a higher level in the future. However, China's reserve for newly added construction land is insufficient, and the contradiction between supply and demand is prominent (a factor that imposes great pressure on China's LC).

T3: Ecological deterioration and geological disasters are leading threats for LC. More than 
$10 \%$ of the country's basic farmland has been polluted by heavy metals. The national loss of soil and water will reach 3.56 million $\mathrm{km}^{2}$ and degraded, desertified or alkalized grassland area will cover 1.35 million $\mathrm{km}^{2}$. In some regions, geological and natural disasters happen frequently. All of the above constitute serious threats to LC in China.

\section{Top-level strategic design for land consolidation}

Based on the listed SWOT identification, we can work out SW strategies and OT strategies by matching and converting internal and external factors (see Tab.1). In this case, the SW strategies mainly aim at characteristics of land consolidation that give advantages and disadvantages over others, providing a possible internal strategic planning framework. Meanwhile, the OT strategies principally try to figure out elements in the environment that could be advantageous to land consolidation or cause trouble for it in terms of an external strategic planning framework. Finally, the SW strategies and OT strategies can be combined into a complete strategic planning framework of land consolidation by taking both internal and external factors into consideration.

Tab.1 SW strategies and OT strategies based on SWOT identifications

\begin{tabular}{|c|c|c|c|}
\hline \multirow{4}{*}{$\begin{array}{c}\text { Inter } \\
\text { nal }\end{array}$} & $\mathbf{S}$ & $\mathbf{W}$ & SW strategy \\
\hline & $\begin{array}{l}\text { A certain amount of experience } \\
\text { has been accumulated }\end{array}$ & $\begin{array}{l}\text { Lack of coordination and objectives } \\
\text { remain singlar (same as for W1) }\end{array}$ & $\begin{array}{l}\text { Top-down and comprehensive } \\
\text { design }\end{array}$ \\
\hline & An extensive base of support & $\begin{array}{l}\text { Insufficient efforts and attention } \\
\text { related to the protection of rights in } \\
\text { rural and urban land }\end{array}$ & Strengthen public participation \\
\hline & $\begin{array}{l}\text { Huge potential and bright } \\
\text { prospects }\end{array}$ & $\begin{array}{l}\text { Lack of support in the forms of } \\
\text { sufficient theoretical preparation, } \\
\text { rational paradigm and strategic } \\
\text { thinking }\end{array}$ & $\begin{array}{l}\text { Improve the legal status of LC } \\
\text { and provide scientific support } \\
\text { of the decision making and } \\
\text { management system }\end{array}$ \\
\hline \multirow{4}{*}{$\begin{array}{c}\text { Exter } \\
\text { nal }\end{array}$} & $\mathbf{O}$ & $\mathbf{T}$ & OT strategy \\
\hline & $\begin{array}{l}\text { The implementation of NRC and } \\
\text { coordinated development of } \\
\text { urban and rural areas in China's } \\
\text { 12th and 13th Five-Year Plans }\end{array}$ & $\begin{array}{l}\text { Severe situation concerning the } \\
\text { protection of agricultural land, } \\
\text { especially cultivated land }\end{array}$ & $\begin{array}{l}\text { Adhere to the "red line" and } \\
\text { give priority to protecting } \\
\text { arable land }\end{array}$ \\
\hline & $\begin{array}{l}\text { Increasingly stronger market } \\
\text { demands for land, especially the } \\
\text { need for construction land. }\end{array}$ & $\begin{array}{l}\text { Mismatch between the supply and } \\
\text { demand for construction land }\end{array}$ & $\begin{array}{l}\text { Optimize the layout of urban } \\
\text { and rural construction land use }\end{array}$ \\
\hline & $\begin{array}{l}\text { Significant attention paid by } \\
\text { China's national government } \\
\text { which is also positively } \\
\text { responded to by local } \\
\text { governments }\end{array}$ & $\begin{array}{l}\text { Ecological deterioration and } \\
\text { geological disasters }\end{array}$ & $\begin{array}{l}\text { Propel a new } \\
\text { landscape-ecological land } \\
\text { consolidation }\end{array}$ \\
\hline
\end{tabular}

\section{$\underline{3.1 \text { SW Strategic Planning Framework }}$}

\section{SW1: Top-down and comprehensive design for the LC implementation}

As previously noted in S1, land consolidation has become a national strategy in China. From the perspective of China's central decisions and arrangements, land consolidation is an integral element 
of the basic requirement of promoting urban and rural development, as proposed in the 17th CPC National Congress (2007). China now urgently needs to improve rural development throughout the country with the help of urban area. So land consolidation is an important tool and platform for implementing the central decisions and arrangements designed to resolve the "Three Rural Issues" 5 under China's urban and rural development goal: expanding domestic demand; improving farmers' production and living conditions; and, more generally, improving production and living conditions in rural areas. Land consolidation is also an essential tool for solving the issue of land demands in urbanization and industrialization as it provides a platform for the exchange of urban and rural resources. This is closely related to the changes of supply in lands designated for urban and rural development with respect to the optimization of spatial patterns of land utilization. In this context, land consolidation should be nationally designed, namely top-down designed, as an important means of integrating capital and increasing efficiency. In this way, the strategic planning framework is able to provide important support for national large-scale investments and promote more effective use of land resources. However, according to W1, land consolidation still suffers a lack of coordination and should lay more emphasis on the relationship between central and local government at various levels. That is to say, the SPFLC should clarify the different responsibilities of all provinces, autonomous regions and municipalities (see Fig.1) as well as incorporating the land consolidation targets into the system of performance evaluation that applies to local governments. Another significant weakness is that objectives of land consolidation still remain singular at this time, and need overall design in the comprehensive designation of areas as field, water, road, forest and village, taking agriculture production, livelihood and ecology into consideration.

\section{SW2: Bottom-up design and encouragement of public participation in accelerating LC implementation}

Based on S2 and W2, land consolidation has already obtained an extensive base of support but still lacks sufficient efforts and attention related to the protection of rights in rural and urban land. To deal with the problem, the strategic planning framework for land consolidation should also include bottom-up design to encourage more public participation in the land consolidation process. In this sense, China should publicize land consolidation to strengthen awareness throughout society and should make full use of various media to provide general knowledge of the annual plan for land consolidation as well as the planning, design and implementation effects of LCP and to enhance public recognition of the achievements. It is essential to strengthen public participation in the formulation and implementation of the land consolidation strategy, which will encourage general recognition of land consolidation's citizen-oriented value and improve the institution of public participation. It is also important to implement a feedback mechanism linking publicity and information exchange. Farmers' participation should be especially emphasized and their opinions should be collected during land consolidation planning and implementation, as well as in the design and engineering of each project. Familiar institutions such as public notifications of the plan, public hearings and a network for the publicity of financial affairs should be incorporated into land consolidation processes. Multiple channels of public participation, including media propagation, public education, social surveying and voting, should enhance land consolidation's interaction with

\footnotetext{
${ }^{5}$ The "Three Rural Issues" are agriculture, rural areas and farmers. In general, the issue of agriculture includes the food security, agricultural production efficiency and trade of agriculture in China. The issue of rural areas includes economic transition in rural areas and the disparity of economic and cultural development between urban and rural areas. The issue of farmers includes improving farmers' income levels, transfer of rural labor and safeguarding farmers' rights.
} 
participants (Yan et al, 1998).

SW3: Improve the legal status of land consolidation and provide scientific support of the management system for land consolidation implementation

Based on the huge potential and bright prospects identified in S3 and on its relatively low legal status, the government, mainly at the national level, needs to actively promote legislative work related to land consolidation, especially to advocate the legislative proposal entitled "Law on Land Consolidation" to ensure that the legal system sufficiently guarantees that land consolidation will be performed. China should also introduce formal regulations on land consolidation as soon as possible, strictly supervising and standardizing the planning and implementation of land consolidation as well as strengthening land consolidation supervision and guidance in general. In addition, China should perfect regulations that support land consolidation, namely the improvement of land tenure administration regulations and relevant supporting policies concerning land displacement and conversion of the quota of newly added arable land in land consolidation, in addition to the formulation of implementing measures for balancing the needs related to the occupation and compensation of arable land (and standardizing this practice). The land consolidation related network of laws and regulations must be constantly evolving, with special laws and regulations established as necessary to meet the demands of the market-based economic system.

Moreover, due to the absence of an effective support system it is necessary to develop a technical support system to ensure the efficiency of land consolidation. Scientific and rational support for the land consolidation process requires, especially in terms of planning and design, necessary specialist equipment, adequate supervision, and technical standards and regulations. At the national level, supporting documents, in the form of "Technical Regulations for Typical Regional Land Consolidation Plan Formation" and "Design Regulations of Rural Land, Water, Road, Forest and Village Consolidation Plans" are urgently needed to guide the formation of regional rural land consolidation plans and the launching of the land consolidation programs. 
Figure $1 \mathrm{SW}$ strategy design of strategic planning framework for land consolidation

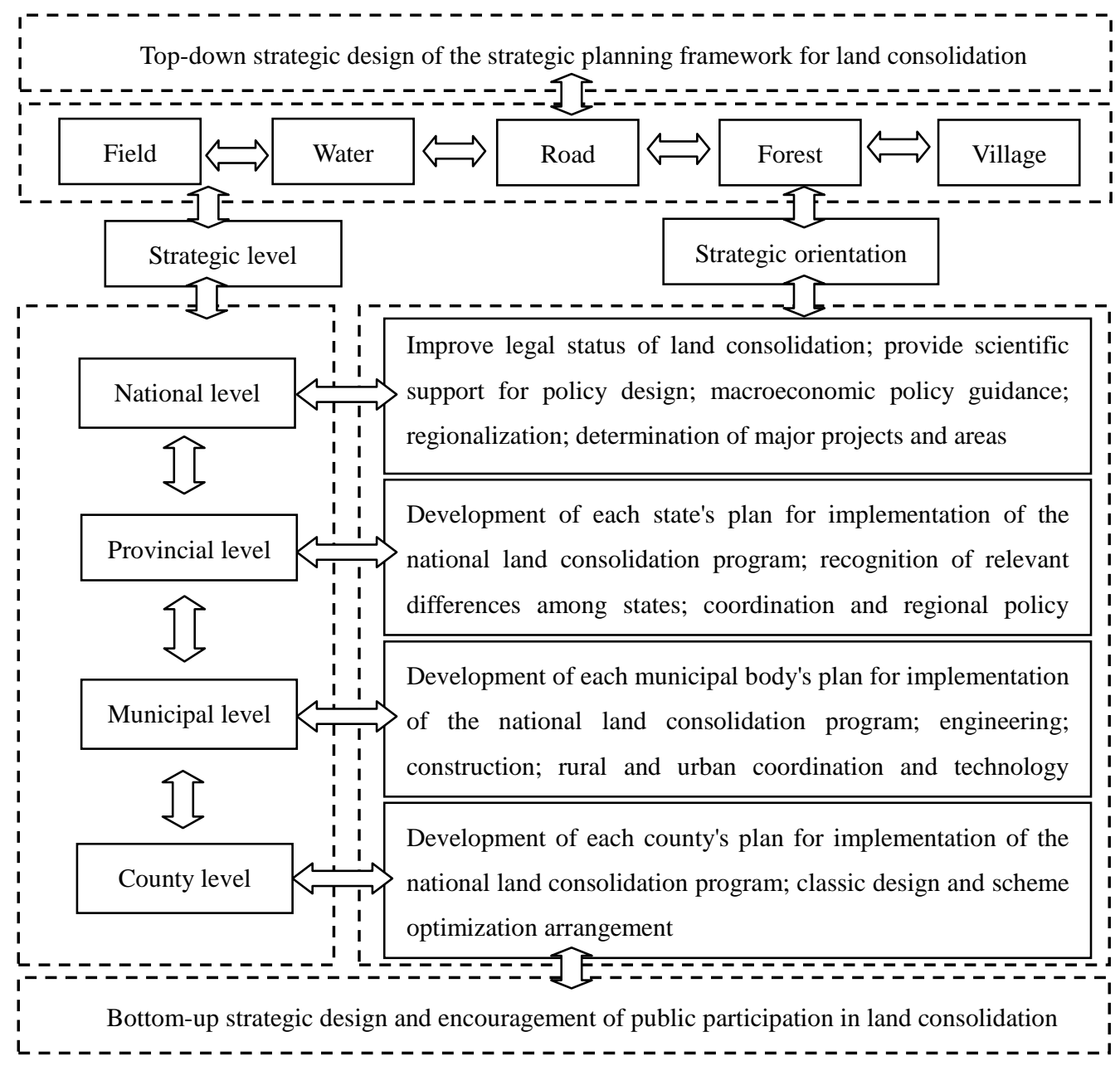

\subsection{OT Strategic Planning Framework}

\section{OT1: Adhere to the "red line," and give priority to the protection of arable land}

Due to $\mathrm{O} 1$ and T1, the implementation of NRC emphasizes the coordinated development of urban and rural areas in China's 12th and 13th Five-Year Plans along with large-scale high-standard farmland being identified as one of the rural essential functions to ensure the grain security for China's future population. Moreover, at the rapid rate of development of modern China, the increasing demands of land tend to transform more infields into construction land, leading to a huge loss of farmland. As a result, land consolidation still needs to adhere to the "red line" and to give priority to the protection of arable land. Particularly in major grain-producing areas, the primary goals of land consolidation should focus more on improving the quality of arable land, enhancing overall grain production and realizing moderate-scale management of agricultural land. In general, China's main grain-producing areas (circled in brown in Figure 2) are the Northeast Plain, the Huanghuaihai Plain and the middle and lower reaches of the Yangtze River. To ensure the safety of grain production and avoid superabundant farmland occupation, China should lay more emphasis on consolidating farmland in these areas; substantially raising the proportion of basic farmland with high and stable yield; strengthening farmland consolidation activities in basic farmland protection areas, major grain-producing areas and (basic farmland) backup areas; advancing the transformation of medium- and low-yield farmland; reclaiming farmland destroyed by natural disasters, production 
and construction activities; improving conditions for irrigation and water conservation; perfecting the supporting infrastructure for farmland production; increasing the amount of arable land by moderating exploitation; and consistently raising farmland quality to ensure national food security. In addition, a reward system for basic farmland protection is also needed.

\section{OT2: Optimize the layout of urban and rural construction land use}

According to the $\mathrm{O} 2$ and $\mathrm{T} 2$, because of the shortage of reserve land resources and the vital function of construction land in the social and economic development of modern China, the discrepancy between supply and demand of construction land keeps widening. Land has already become one of the scarcest recourses and this problem is even more serious in the areas of rapid urbanization. To solve this urgent problem, land consolidation should aim at the targets of optimizing the layout of urban and rural construction land use. To some extent, the most significant disparities often exist in China's areas of rapid urbanization, which land consolidation should primarily address. This includes most of middle China as well as the well-developed eastern areas and the fringe areas surrounding cities. The government needs to promote intensification and economically sound use of land while focusing on the consolidation of lands designated for development. China needs to recognize the important role of development-land consolidation in meeting the land demand associated with social and economic development; strengthen the management of rural construction; make reasonable arrangements for the relocation and merging of villages; consolidate old villages, suburban villages, villages in the city and areas susceptible to geological disasters; establish and improve the mechanism for the transformation and use of homesteads; develop and impose standards for pilot sites linked to the increase and decrease of development lands; recover urban lands that might be appropriate for development or for rural non-agricultural purposes; and promote intensification and economic efficiency in the use of rural and urban land.

\section{OT3: Propel a new landscape-ecological land consolidation}

As shown in T3, land consolidation faces a number of ecological problems and always ignores the need to protect the environment. In a sense, it should be indicated that land consolidation in China has not yet entered the stage of landscape-ecological protection focusing both on improving the quality of living environments and production quality of farmland. However, as an important tool and platform of urban and rural work as described in O3, these problems appearing in some areas, especially ecologically vulnerable areas, are particularly harmful and so land consolidation should propel a new landscape-ecological pattern to protect the ecological environment and the natural and cultural landscape. China's ecologically vulnerable areas (circled in green in Figure 2) normally include the northern ecologically vulnerable area, the cave-dwelling area in the Northern Loess Plateau, the northwest arid inland area, the Yunnan-Guizhou Plateau multi-ethnic mountainous area and the southern ecologically vulnerable area. In these areas, land consolidation needs to improve the overall environmental quality of land resources through ecological restoration. These measures must be designed to address local land-use issues and compliant with the laws governing the protection of water bodies such as rivers, reservoirs, irrigation canals and ditches. These efforts need to restore and reconstruct ecosystems; control salinization and stony desertification; and improve soil quality. After land parcels are consolidated and ready for the new use, ecological requirements should be highlighted in land use processes. To maintain and improve people's productivity and the quality of their living conditions, the government should strictly 
prohibit any attempt to arbitrarily change topographic features.

Figure 2 OT strategy design of strategic planning framework for land consolidation

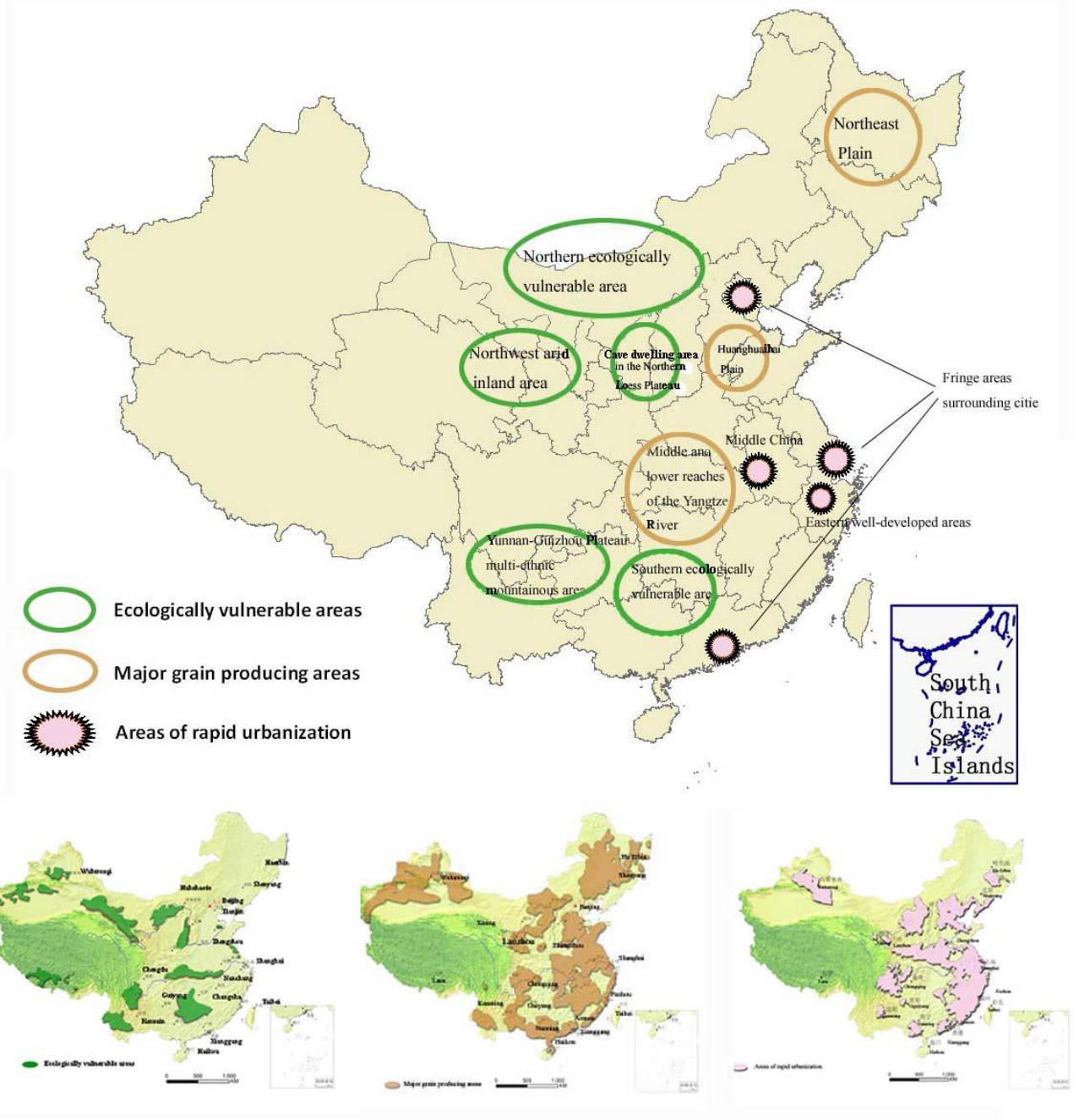

\subsection{Strategic planning framework for land consolidation in China}

Overall, in terms of the internal factors, the SPFLC should provide strong protection for continuous promotion of land consolidation through application of top-down and comprehensive design considering agriculture production, livelihood and ecology as comprehensive targets. In addition, clear institutional norms with strict obligations of government at all levels and a sound bottom-up land consolidation public participation mechanism should be established with strong scientific and technical support. Moreover, in terms of the external circumstance effects, SPFLC should unswervingly adhere to the "red line," which specifies the lowest limit on the amount of arable land that must be maintained, and fully implement tasks identified for the supplementation and quality improvement of cultivated lands. Further, SPFLC should optimize the layout of urban and rural land use, especially the balance of construction land, and vigorously promote the consolidation of land for rural development, industrial development and mining as a means of adjusting village spatial structures. While striving to further intensify land use and greatly reduce the income gap between urban and rural areas, SPFLC should lay more emphasis on the protection of the urban and rural environment, propelling a new landscape-ecological land consolidation. As 
the three most significant areas figured out in the OT strategy, SPFLC should consider local endowments and regional diversity on major grain-producing areas, ecologically vulnerable areas and areas of rapid urbanization. In short, land consolidation should organically integrate production, life and ecology while constantly improving land utilization and productivity to meet the requirements that social and economic development impose on land resources and to ensure the rational use of land resources. China will achieve a new stage of landscape-ecological land consolidation, thereby making a thriving ecosystem and spectacular sustainable utilization possible.

\section{Conclusions and discussion}

Based on the SWOT analysis and SPFLC design, the discussion in this paper leads to four conclusions. First, China has reached a transformational stage of development. Land consolidation in China has not yet entered the stage in which it takes on landscape-ecological protection focusing on improving the quality of living environments and production quality of farmland, but it is on the brink of that stage. Under guidance that calls for "maintaining rapid growth while sticking to the principle of protecting arable land," China's current mission of land consolidation still needs to undertake increasing arable land as a primary task in order to realize a dynamic equilibrium with regard to the country's total arable land (Yan et al, 1998). China faces a number of problems in land consolidation, including the difficulty of getting different stakeholders to identify and accept an unified target; tendencies to put quantity ahead of quality, area ahead of benefit and land ahead of farmers; lack of an overall arrangement for integrating farmers' productivity and livelihoods with the need to protect and improve environment; and the habit among many of ignoring the need to protect the environment. At present, China has set out to address the problem of cultivated land quality, but the problem of cultivated land area is yet to be solved. Environmental problems are also currently on the agenda. To end its dilemma, China needs to actively guide land consolidation in the transformation to modern land consolidation, specifically in terms of landscape-ecological land consolidation and pushing land consolidation and relevant planning forward toward the goal of combining landscape with production, livelihoods and ecology (Wang et al, 2014).

Second, various departments have carried out much independent work in the development of farmland, water, roads, forests and villages. Although these works have yielded good results individually, there has been a lack of coordination between these efforts. Land consolidation is the fundamental requirement for advancing urban and rural development, as well as a key measure in coordinating and unifying the new development of rural areas and modern agriculture. To this end, land consolidation must follow the objectives and land uses defined in overall planning. Land consolidation must employ a series of administrative, economic, legal and engineering means to transform the old view of consolidation, which has arable land as its core, into the new view, which takes farmers as its core, farmland and communities as its focus and water, forests and villages as its support.

Third, the overall SPFLC at the regional level should seek methods for addressing technical, management and implementation issues according to each region's distinctive features. It will be valuable to set up models in typical regions to provide a basis for research and discussion of issues related to planning and design, engineering technology, consolidation equipment and project supervision. In this process, it will be useful to consider five possible combinations for the linkage of land consolidation with (i) the upgrading of medium- and low-yield farmlands, (ii) moderate-scale agriculture operations, (iii) promotion and demonstration of new processes, technology and equipment, (iv) agricultural modernization and mechanization and (v) land 
consolidation project supervision.

Finally, in the process of land consolidation, China should vigorously promote the delimitation of property rights in rural land, strictly standardize the acts of local governments and safeguard the fundamental interests of landowners, especially farmers. With regard to ownership adjustment, resident relocation and allocation of funds to the land consolidation process, China should give full play to the role of collective economic organizations while properly handling profit distribution among the government, developers, village collectives and farmers. In profit distribution, a higher proportion of differential rent should be returned to landowners (that is, to rural collective organizations and farmers), thereby enabling farmers to share the benefits of achievements in industrialization and urbanization. In land consolidation, village-level collective economic organizations should be allowed to participate in the planning and layout of the residential areas and in later industrial development. Issues, such as the relevant history and culture; environment and resources; economic crop resources; and other comparative advantages, need full consideration to advance the development of a new socialist countryside in a reasonable way.

\section{Acknowledgements}

This work was supported by the Major Program of the National Social Science Foundation of China (grant no. 09\&ZD047) and the National Key Technology Research and Development Program of the Ministry of Science and Technology of China during the $12^{\text {th }}$ Five-Year Plan Period (grant no. 2012BAB11B02). The insightful and constructive comments of the anonymous reviewers are appreciated.

\section{Reference}

1. Choguill, C.L. (1999).Community infrastructure for low-income cities: the potential for progressive improvement. Habitat International, 23(2), 289-301.

2. Crecente ,R., Alvarez, C., Frau, U. (2002). Economic, social and environmental impact of land consolidation in Galicia. Land Use Policy, 19 (2), 135-147

3. Ding, C.R. (2003).Land policy reform in China: assessment and prospects. Land Use Policy, 20 (2), 109-120

4. Gonzalez, X.P., Alvarez,C.J., Crecente, R. (2004). Evaluation of land distributions with joint regard to plot size and shape. Agricultural Systems, 82 (1), 31-43

5. Graaf, Robin S.de, Dewulf, GeertP.M.R.(2010).Applying the lessons of strategic urban planning learned in the developing world to the Netherlands: A case study of three industrial area development projects. Habitat International, 34(4), 471-477

6. Halla, F. (2002).Preparation and implementation of a general planning scheme in Tanzania: Kahama strategic urban development planning framework. Habitat International, 26(2), 281-293.

7. Halla, F. (2007).A SWOT analysis of strategic urban development planning: the case of Dares Salaamcity in Tanzania. Habitat International, 31(1), 130-142.

8. Halla, F., Majani, B. (1999). The environmental planning and management process and the conflict over outputs in Dar-es-Salaam. Habitat International, 23(3), 339-350.

9. Huang, Q.H., Li, M.C., Chen, Z.J., Li, F.X. (2011).Land consolidation: an approach for sustainable development in rural China. AMBIO, 39 (1), 93-95 
10. Li, X.B., Wang, X.H. (2003). Changes in agricultural land use in China: 1981-2000.Asian Geographer, 22(1-2), 27-42

11. Li, Y.; Liu, Y.; Long, H.L.; et al. (2014). Community-based rural residential land consolidation and allocation can help to revitalize hollowed villages in traditional agricultural areas of China: Evidence from Dancheng County, Henan Province. Land Use policy, 39, 188-19

12. Lin, G.C.S., Ho, S.P.S. (2003). China's land resources and land-use change: insights from the 1996 land survey. Land Use Policy, 20 (2), 87-107

13. Lin, G.C.S. (2010). Understanding land development problems in globalizing China.Eurasian Geography and Economics, 51 (1), 80-103

14. Liu, Y. (2011). Scientifically promoting the strategy of reclamation and readjustment of rural land in China. China Land Science, 4, 3-8 (in Chinese)

15. Liu, Y.S., Liu, Y. (2010). Progress and prospect on the study of rural hollowing in China. Geographical Research, 29 (1) (2010), 35-42 (in Chinese)

16. Long, H.L., Liu, Y., Li, X., Chen, Y. (2010). Building new countryside in China: a geographical perspective. Land Use Policy, 27 (2) , 457-470

17. Long, H.L., Zou, J., Pykett, J., Li, Y. (2011). Analysis of rural transformation development in China since the turn of the new millennium. Applied Geography, 31 (3), 1094-1105

18. Long, H.L., Li, Y., Liu, Y.et al. (2012). Accelerated restructuring in rural China fueled by 'increasing vs. decreasing balance':land-use policy for dealing with hollowed villages. Land Use Policy, 29 (1) ,11-22

19. Long, H.L. (2014). Land consolidation: an indispensable way of spatial restructuring in rural China. Journal of Geographical Sciences, 24 (2) ,211-225

20. Miranda, D., Crecente,R., Alvarez, M.F. (2006). Land consolidation in inland rural Galicia, N.W. Spain, since 1950: an example of the formulation and use of questions, criteria and indicators for evaluation of rural development policies. Land Use Policy, 23 (4), 511-520

21. Nguyen, T., Cheng, E., Findlay, C. (1996). Land fragmentation and farm productivity in China in the 1990. China Economic Review, 7(2), 169-180

22. Ogu, V.I. (2000).Stakeholders' partnership approach to infrastructure provision and management in developing world cities: lessons from the Sustainable Ibadan project. Habitat International, 24(4), 517-533.

23. R. Crecente, C. Alvarez, U. Frau. (2002). Economic, social and environmental impact of land consolidation in Galicia. Land Use Policy, 19 (2), 135-147

24. Reerink, G., Van Gelder, J.L. (2010). Land titling, perceived tenure security, and housing consolidation in the kampongs of Bandung, Indonesia. Habitat International, 34 (1), 78-85

25. Scolozzi, R., Schirpke, U., Morri, E., et al. (2014).Ecosystem services-based SWOT analysis of protected areas for conservation strategies. Journal of environmental management, 146, 543-551

26. Sorensen,A. (2000). Conflict, consensus or consent: implications of Japanese land readjustment practice for developing countries. Habitat International 24(1):51-73.

27. Steinberg, F. (2005).Strategic urban planning in Latin America: experiences of building and managing the future. Habitat International, 29(1), 69-93.

28. Tan, S.H., N. Heerink, F.T. Qu. (2006). Land fragmentation and its driving forces in China. Land Use Policy, 23(3), 272-285 
29. Van Dijk, T. (2000). Effects of land consolidation in practice analysis of post-war experience in The Netherlands. E.M. Fendel (Ed.), Proceedings of 22nd Urban and Regional Data Management Symposium-Seminar on Land Markets and Land Consolidation in Central Europe, Delft, TU Delft Coelho, J.C., Pinto, A.P., M.L. Silva. (2001). A systems approach for the estimation of the effects of land consolidation projects (LCPs): a model and its application. Agricultural Systems, 68(3), 179-195

30. Van Dijk, T. (2007).Complications for traditional land consolidation in Central Europe. Geoforum, 38 (3), 505-511

31. Van lier, H.N. (2000). Land use planning and land consolidation in the future in Europe. Zeitschrift fur Kulturtechnik und Landentwicklung, 41 (3) , 138-143

32. Wang, H., Wang, L., Su, F., Tao, R. (2012). Rural residential properties in China: land use patterns, efficiency and prospects for reform. Habitat International, 36 (2) , 201-209

33. Wang, J.Y., Liu, Y.S., Chen, Y.F. (2010). Spatial expansion pattern and its dynamic mechanism of typical rural settlements in Huang-Huai-Hai Plain. Geographical Research, 29 (10), 1833-1840 (in Chinese)

34. Wang, Q., Zhang, M., Cheong, K. (2014). Stakeholder perspectives of China's land consolidation program: A case study of Dongnan Village, Shandong Province. Habitat International, $43,172-180$

35. Wittlingerova, Z., Kriz, L. (1998). The effect of anthropogenic activities on the chemical properties of ground waters. Rostlinna Vyroba, 44 (2), 321-324

36. Wong, S. W., Tang, B., VanHoren, B. (2006). Strategic urban management in China: A case study of Guangzhou Development District. Habitat International, 30(3), 645-667.

37. Wu, C., Fei, L., Ye, Y. (2011). The theoretical perspective, rational paradigm and strategic solution of land consolidation. Economic Geography 10, 1718-1722 (in Chinese)

38. Xia, F., Yan, J. Liu, J.(2014). Research on governance path of rural settlements reconstruction patterns. Transactions of the Chinese Society of Agricultural Engineering (Transactions of the CSAE), 30(3), 215-222(in Chinese)

39. Yan, J. (2010). China's land use and planning research strategy. Beijing: China Land Press (in Chinese)

40. Yan, J., Xia, F., Li, Q. (2012). Top strategy design of comprehensive land consolidation in China. Transactions of the Chinese Society of Agricultural Engineering, 28(14), 1-9(in Chinese)

41. Yan, J., Zhong, J., Chi, G. (1998). Land Consolidation. Beijing: Economic Management Publishing House (in Chinese)

42. Yu,G., Feng, J., Che, Y. et al. (2010). The identification and assessment of ecological risks for land consolidation based on the anticipation of ecosystem stabilization: A case study in Hubei Province, China. Land Use Policy 27(2), 293-303.

43. Yun, W., Yu, Z. (2011). Ecological landscaping strategy of rural land consolidation in China. Transactions of the Chinese Society of Agricultural Engineering 27(4), 1-6 (in Chinese)

44. Zhang, Z., Zhao, W., Gu, X.(2014). Changes resulting from a land consolidation project (LCP) and its resource-environment effects: A case study in Tianmen City of Hubei Province, China. Land Use policy, 40, 74-82

45. Zhao, Y. (2011). China's land tenure reform: time for a new direction?, The China Review, 
2, 125-152. 